\title{
A Primer on the LAW in the United States: Part III Scope of Liability in Product Liability Cases
}

\author{
Richard J. Hunter, Jr. (Corresponding Author) \\ Department of Economics and Legal Studies \\ Seton Hall University, South Orange, New Jersey, United States 07079 \\ Telephone: 973-761-9511 \\ E-mail: Richard.Hunter@shu.edu \\ Henry J. Amoroso \\ Department of Economics and Legal Studies \\ Seton Hall University, South Orange, New Jersey, United States 07079 \\ E-mail: Henry.Amoroso@shu.edu \\ John H. Shannon \\ Department of Economics and Legal Studies \\ Seton Hall University, South Orange, New Jersey, United States 07079 \\ E-mail: John.Shannon@shu.edu
}

Accepted: June 18, 2012 Published: July 04, 2012

Doi:10.5296/ijld.v2i4.2049 URL: http://dx.doi.org/10.5296/ijld.v2i4.2049

\begin{abstract}
In Part III of our study, the authors describe the types of transactions that are most common in products liability cases and also delineate the parties to the transaction. This article concludes by discussing some "special topics" in modern product liability law: enterprise liability, alternative liability, and market share liability. The article relies on references to the Uniform Commercial Code, the Restatement of the Law of Torts, and cites the major common law cases that have impacted on these important issues.
\end{abstract}

Key Words: Products Liability; Bailments; Franchising; Used Goods; Enterprise Liability; Market Share; Alternative Liability

\section{Types of Transactions}

We will begin the discussion of the scope of liability in products liability cases by looking at the definition of strict liability. "A manufacturer is strictly liable in tort when an article he places on the market, knowing it is to be used without inspection for 
defects, proves to have a defect that causes injury to a human being." (Greenman v. Yuba Power Products, Inc., 1963).

Based upon this notion of "placing a product on the market," most courts today regularly and uniformly apply strict liability to both sale and to lease transactions, holding that there is little difference in supplying products to the public in either a sale or a lease transaction. But that was not always the case!

A sale may be described as the "passing of title between a seller and a buyer for a price." (Uniform Commercial Code (UCC) Section 2-401, 2001). Section 402A of the Restatement of Torts (1965), setting forth the requirements for the imposition of strict liability, would obviously apply to a sale, since its language, "one who sells a product...," is both straightforward and direct. Likewise, an action based on the theory of a breach of warranty (either express or implied-most especially, based upon a breach of the implied warranty of merchantability found in UCC Section 2-314(2)) would be applied in the case of a sale of a good, since Sections 2-313-315 specifically refer to a sales transaction. However, the question remains: Can liability be expanded or is a "sale" strictly required for liability to be applied?

\section{Other Transactions}

In Martin v. Ryder Truck Rental, Inc. (1976), the Supreme Court of Delaware noted that "the common law must grow to fulfill the requirements of justice as dictated by changing times and conditions." Since the 1970s - at least - liability has been expanded to a variety of other transactions, depending on the specific facts developed in individual cases.

\subsection{Bailments or Leases of Items of Personal Property}

In recent years, it has become clear that most courts will apply strict liability to a lease, but only if the lessor is "in the business" of leasing products of this kind, and where the product itself has been "introduced into the stream of commerce" through a lease. The extension of the doctrine of strict liability has been limited, however, to those leases made "in the regular course of the rental business." $\quad$ A bailment for hire or mutual benefit bailment is a special type of lease of personal property [the common law used the term "chattel"] that involves the temporary surrender of an item of personal property from the bailor or lessor to the bailee or lessee with a provision for its return, in which the bailor is usually compensated in some way. In such a case, if the property proves to be defective in production, design, or because of the inadequacy of warnings, the bailor/lessor may be held liable.

In other cases, there are major difficulties in imposing strict liability and proof of negligence is usually required. As opposed to strict liability, negligence is commonly defined as "the failure to do something which a reasonably careful person would do, or the 
doing of something which a reasonably careful person would not do" under the particular circumstances of the case. (Mangrum v. Pigue, 2004).

\subsection{Franchising}

In Kosters v. Seven-Up Co. (1979), the court imposed liability because 7-Up, as the franchiser, had exercised control over the "type, style, size, and design" of the carton under its important "quality control" obligation. With knowledge of its design, 7-Up consented to the entry of this product "into the stream of commerce," and thus should be held liable for any injuries caused by a defect in their product. In Kosters, the Court of Appeals for the Sixth Circuit noted that liability would arise from several factors in combination: injury;

1. The risk created by approving for distribution an unsafe product likely to cause

2. The franchiser's ability and opportunity to eliminate the unsafe character of the product and prevent the loss;

3. The consumer's lack of knowledge of the danger; and

4. The consumer's reliance on the trade name which gives the intended impression that the franchiser is responsible for and stands behind the product.

\subsection{Publications}

In Cardozo v. True (1977), a Florida court dealt with the question of the imposition of strict liability in the case of a publication. In such a case, there is an additional consideration - the First Amendment-which may implicate the freedom of commercial speech (freedom to publish), discussed in the important cases of Gertz v. Robert Welch, Inc. (1974) and Time Inc. v. Firestone (1976). In True, the court noted: "To hold those who perform this essential function liable, regardless of fault, when an injury results would severely restrict the flow of ideas they distribute." Thus, in the case of a publication, the plaintiff would have to show more than mere publication, which might be the equivalent of adopting a strict liability standard, and would have to prove some negligence on the part of the publisher.

Liability, however, has been applied to certain publications-most notably air and sea navigation charts, where the defect occurred as a result of either faulty surveying (which might be roughly equivalent to a defect in design) or perhaps faulty printing (which might be roughly equivalent to a production defect). (Flour Corp. v. Jeppesen \& Co., 1985). There is also a potential liability issue for certain parties called "product certifiers," for example, Good Housekeeping or United Laboratories, who must use "reasonable care" in their certification or evaluation of products. If they fail to use "reasonable care," these "product certifiers" may be held liable for their negligence if an injury ensues. (Hempstead v. General Fire Extinguisher Corp., 1967).

\subsection{Used products}


In Tillman v. Vance Equipment Co. (1979), the Supreme Court of Oregon held that a seller of a used crane would not be strictly liable in tort for a defect where the defect was created by the manufacturer, and not the seller of the used product. The court noted that the imposition of strict liability would not be appropriate because there is no real expectation of absolute safety on the part of a buyer under the circumstances of a sale of a used item.

Retailers are certainly an integral part of the overall production and marketing enterprise-most especially in cases of sales of food products and children's toys-sometimes called the so-called "implied representational aspect" of a seller. (Mongoven, 2007). Thus, retailers should and often do bear some of the responsibilities and costs for defective products. Under normal circumstances, a retailer may play a substantial part in insuring that a product is safe or in "exerting pressure on a manufacturer to that end." (Peterson v. Lou Backrodt Chevrolet Co., 1975; Harber v. Altec Industries, Inc., 1993). However, a seller of used goods is not in such a unique position to insure the absence of any defect and would not bear this general responsibility. A seller of used goods, however, might be liable for negligence if that party caused a defect through or by improper preparation, or maintenance, or if the seller of used goods knew about a defect, and/or failed to warn a prospective buyer.

The issue of indemnity is also important in determining the responsibility of the retailer, and by extension, the seller of used goods. Under normal circumstances, where a retailer has been held liable in a product liability case, an "innocent" retailer (one who has him or herself not been negligent) is able to seek indemnity from the manufacturer. In the case of used goods, there may be significant problems with a statute of limitations because of the passage of time, or with locating a solvent manufacturer-if one even exists!

In the case of the warranty of merchantability, such a warranty may be applicable to the sale of used goods but "only to the extent reasonable." In reality, however, warranties can be disclaimed and in most cases, used goods will be sold "as is" or "with all faults"-negating all potential warranties-including the protections of the warranty of merchantability under UCC Section 2-316(2), provided that the language of the disclaimer specifically mentions "merchantability" and, if the disclaimer is in writing, it must be “conspicuous.” (Tennessee Carolina Transportation, Inc. v. Strick Corp., 1973).

\subsection{Real Property Cases}

In Kriegler v. Eichler Homes, Inc. (1969), the plaintiff complained about a failure of a heating system, characterized as a design defect, in a home constructed and sold by Eichler Homes. These homes are called "manufactured, modular, or development homes" to distinguish them from individually built homes. (Del Mar Beach Club Owners v. Imperial Contracting, 1981). 
Kriegler is essentially a "public policy" or case of first impression, where a court must interpret the purpose and effect of strict liability and determine if strict liability should be extended into this area, previously not considered as appropriate for the imposition of strict liability. The Kriegler court held that there was essentially no difference in the mass production and sale of such homes and the mass production and sale of autos. However, the court refused to adopt a strict liability standard and noted that the test in such circumstances would be that of reasonableness - a negligence standard - and not strict liability where the builder would be held essentially as an insurer under all circumstances. As we know, warranties under the UCC do not apply to real estate transactions since the warranty provisions under Article 2 and Article 2A generally apply to the sale/lease of movable and tangible goods. (G-W-L, Inc. v. Robichaux, 1982). It is possible that other courts might apply the warranty of habitability to such transactions, and not the law of products liability at all. (Humber v. Morton, 1968).

The law in the area of real property is both new and spotty. Kriegler seems to have settled the law in so far as "mass produced" or "manufactured housing."

\subsection{Landlord-Tenant Cases}

In landlord-tenant cases, liability for any defects in the premises most often applies where there is a latent or hidden defect as opposed to an "open or obvious" or "patent" defect (N.J. Statutes Annotated, 2000), or where there has been a concealment of a known danger by the landlord, or where there is an independent contractual duty to repair undertaken by the landlord and the landlord fails to make the required repairs.

In Becker v. IRM Corp. (1985), Justice Broussard noted that the common law placed the risk concerning the suitability of the property for a use contemplated by the parties on the tenant. Today, there is a clear trend to increase the responsibility of the landlord to provide the tenant with property in a "condition suitable for the use contemplated by the parties." This is termed as the "warranty of habitability." (McNally v. Ward, 1961.) The Becker court said that liability would be applied to a landlord who is engaged in the business of leasing dwellings when the defect existed at the time the premises were leased to the tenant. The landlord is in a better position to bear the costs of injury due to defects in the premises rather than the tenant. This view, however, is not universally held and the imposition of liability changes from state to state. In landlord-tenant cases, most states would apply a negligence standard rather than one in strict liability.

Even in states that follow Becker, decisions relate only to the initial lessor or landlord and hold that a subsequent purchaser of property, who has not installed, altered or created the condition and who does not have actual or constructive knowledge of any defect, should not be held to a strict liability standard. Liability for negligence (a "reasonable landlord" standard) would apply. 
2.7 Services

Courts have been reluctant to extend the definition of a "product" beyond the article manufactured or supplied, and not to the process under which it is supplied or perhaps installed.

There are two types of service transactions: pure services and hybrid or mixed transactions that involve both a product and a service. A hint as to how these transactions will be considered may be found in the treatment of hybrid transactions under the Uniform Commercial Code. For the purpose of applying the UCC, courts must decide what the essence of the transaction is and which portion (either goods or services) predominates. Courts will generally not apply strict liability at all to pure services, relying instead a negligence standard. (Gagne v. Bertran, 1954). Thus, a pure service transaction where strict liability would not be applied may best be described as follows:

\section{The negligent installation of a non-defective product}

Thus, in a mixed or hybrid transaction, it is clear that the product itself must be defective. For example, a New Jersey court held a beauty shop strictly liable when a defective permanent wave lotion was applied to a patron's hair. (Newmark v. Gimbel's Inc., 1969).

Other courts disagree and have held that if a service component is involved at all, strict liability is not appropriate. For example, in Mogrine v. Spector (1968), the plaintiff was injured when a defective needle, being used by a dentist, broke off in the patient's gum. The court rejected a strict liability standard. A negligence standard was instead applied.

In the case of professionals who render a service, courts will uniformly require proof of negligence. However, the standard of reasonableness will be that of a "professional under such circumstances." In practical terms, this standard of "due or reasonable care" will be higher than that of the ordinary, reasonable man because of the training required of a physician, lawyer, or some other professional. (Mongoven, 2007).

\section{Parties to the Transaction}

In the main, the tendency to expand the scope of both plaintiffs and defendants is a notable characteristic of the modern law of products liability. Potential plaintiffs in a products liability case include buyers, users, consumers, and/or any foreseeable parties, including bystanders. (Kiely \& Ottley, pp. 95-100, 2006; Section 402A). The expansion of liability to a wide variety of potential plaintiffs reflects a policy "to insure that the costs of injuries resulting from defective products are borne by 
the manufacturers that put such products on the market rather than by the injured persons who are powerless to protect themselves." (Elmore v. American Motors Corp, 1969).

Potential defendants generally include all parties in the normal chain of distribution of a product. The state of California provides the most extensive list of potential defendants as parties involved in "designing, manufacturing, purchasing, producing, constructing, assembling, preparing, testing, inspecting, maintaining, repairing, installing, endorsing, selling, bailing, licensing, or otherwise marketing..." a product. [Manufacturers: Greenman v. Yuba Power Products, Inc., 1962; apparent manufacturers: Long v. United States Brass Corp., 2004); wholesalers and distributors: Fuchsgruber v. Custom Accessories, Inc., 2001; assemblers: Weyerhaeuser Co. v. Thermogas Co., 2000); retailers: Moss v. Polyco, 1974; dealers: Sabloff v. Yamaha Motor Co., 1971); persons who sell or distribute as their own products manufactured by another: Restatement (Third) of Torts, Section 14 (1998); trademark licensors: Torres v. Goodyear Tire \& Rubber Co., 1990; and lessors and bailors: Kemp v. Miller, 1990)]. This statement reflects the viewpoint found in Section 1 of the Restatement (Third) of Torts which imposes liability on "one engaged in the business of selling or otherwise distributing products who sells or distributes a defective product." Who are these parties?

- The manufacturer or final assemblers or the manufacturer of a component part that proves to be defective: In general, the manufacturer or final assembler of a product that is found defective is the most likely party to be held liable since strict liability permits an injured party to sue the manufacturer directly, in the absence of the former requirement of privity of contract. Under modern methods of manufacturing and marketing, there is another type of manufacturer: "A manufacturer who puts out as his own a product a chattel manufactured by another is subject to the same liability as though he was the manufacturer, and in some cases, a retailer who sells products under his own name (retailer-brand name products)." (Bell v. Industrial Vangas, Inc. 1981; Restatement (Third) of Torts, Section 14, 1998). Giant retailers frequently sell products they themselves do not manufacture under their own brand name.

In such a case of "branding" or "seller masking" of a product, the retailer would be able to seek indemnity from the actual manufacturer. It is a wholly different matter if the actual manufacturer is foreign-based, or not subject to legal process, or has filed for bankruptcy protection.

- Retailers, wholesalers, and distributors: Under Comment f of Section 402A, which provides for the imposition of strict liability, liability is imposed on any party "engaged in the business of selling a product for use or consumption" i.e., the manufacturer, wholesaler, retailer, or distributor, or perhaps even the owner or the operator of a restaurant.

In negligence cases, it may be difficult to prove negligence against a non-manufacturer seller, since such a party is normally a "mere conduit" with no affirmative 
duty to inspect a product or test a product for defects. This may be seen as the "essence" of the privity rule of the common law that insulated manufacturers from liability (under the rubric of caveat emptor) and held the non-negligent retailer harmless from liability. However, if a retailer does undertake to inspect, test or assemble a product, it may be liable for failing to do so "with reasonable care." Ironically, this distinction may prove as a disincentive to a retailer to do anything more than offer a product for sale.

In Vandermark v. Ford Motor Co. (1964), involving a suit against both Ford Motor, the manufacturer, and Maywood Bell Ford, the retailer, the Supreme Court of California, through Justice Traynor, held that the retailer, "engaged in the business of distributing goods to the public," may in fact be in a very good position to "exert pressure on the manufacturer" to assure safety and the imposition of liability in such circumstances serves as an "added incentive" to safety.

There are some interesting and important exceptions or minority views, grounded in state law or arising in cases decided in state courts:

- There is a widely held exception where a product is sold by a retailer in a " sealed container";

- Where the basis of liability is for a latent defect that was not discoverable by reasonable inspection by the retailer;

- Some states have enacted specific statutes that may exempt retailers from strict liability (Colorado, Kentucky, or Tennessee) on policy grounds.

Under warranty actions, because of the manner in which an express warranty or the warranty of fitness for a particular purpose is created, an express warranty or implied warranty of fitness would only be applicable to a seller whose words or conduct created these warranties. In contrast, the warranty of merchantability (in which there is an implied promise that goods are "fair, average quality" or are "fit for their ordinary purposes") is applicable to all sellers in the chain of distribution, but only if such parties are merchants. [Under the Uniform Commercial Code, Section 2-104(1), a merchant is defined as one who deals in goods of that kind on a regular basis or someone who holds themselves out as having special knowledge about such goods-generally referred to as an expert. (Lish v. Compton, 1976).]

In a case involving the warranty of merchantability, the product must somehow "pass through" the defendant's hands and the seller must be engaged in selling that particular product. Thus, the warranty of merchantability does not apply to the casual or occasional seller. 
It is also important to note that a retailer or wholesaler or any other party other than the manufacturer who is held liable under a theory of strict liability and who himself has not committed a wrong in the traditional "negligence" sense (and thus may be termed as an "innocent seller") would be entitled to seek indemnity from the manufacturer or some other party - if that party can be found and is available!.

- Used product sellers:

Most courts have held that strict tort liability is not applicable to a seller of used products. (Bruce v. Martin Marietta Corp., 1976). As a matter of policy, courts will simply not hold a seller of used goods liable where the defect is due to a flaw in the manufacture or design of the product.

However, in a case where a court holds a used product seller strictly liable because of a defect in the product itself, the used product seller can also seek indemnity from the manufacturer. Remember, however, the application of the statute of limitations or the availability of the original manufacturer may make indemnity impossible or impractical!

The warranty of merchantability is applicable to the sale of used goods, but only to the extent "reasonable under the circumstances." Does this sound like a variation of the "consumer expectations test"?

In the case of used goods, one who undertakes to rebuild or repair a used product can be held liable if that work results in a defectively built used product. The theory of strict liability might be available in such cases because in effect, the rebuilt product may be considered "new" or perhaps "good as new." Of course, if repairs are done improperly, the party can also be held liable for any negligent repairs. (Contra, Mid Continent Aircraft Corp. v. Curry County Spraying Services, Inc., 1978).

- "Successor corporations":

Consider the following question: Can a successor corporation (SC) that purchases the business or assets of another corporation be held strictly liable for injuries caused after the business purchase by a defective product sold by the prior corporation (PC) before the purchase?

Under the common law, liability would only be imposed under the following circumstances:

1. The successor corporation expressly or impliedly assumed the obligations of the original corporation;

2. There was a "de facto" merger of the two entities; (Reilly, 2000; Philadelphia Electric Co. v. Hercules, Inc., 1985) 
3. There was a "mere continuation" of the original enterprise, despite any technical change in the business form;

4. There was a fraudulent effort or sham to avoid the liabilities of the predecessor. (Dayton v. Peck, Stow, \& Wilcox Co., 1984; Bernard v. Kee Manufacturing Co., Inc., 1972).

The common law has become a bit more specific and today, there are two main theories providing for liability in cases of successor corporations. The first is called the continuity of the enterprise or the "mere continuation" rule of Turner v. Bituminous Casting Company (1976). There are four aspects of this rule:

- There is a continuity of management, personnel, physical location, assets and general business of the predecessor;

- There has been a dissolution of the predecessor and only one entity remains;

- There has been an assumption by the successor of certain liabilities of the predecessor necessary for continuation of normal business operations;

- "Holding out" of itself to the public by the successor as the effective continuation of the predecessor.

The second exception is termed as "the product line exception," where the successor acquires all or substantially all of the manufacturing assets of the predecessor, or undertakes essentially the same manufacturing operations.

Both the "product line exception," found in three states, and the "mere continuation" rule of Turner $v$. Bituminous Casting are based on a policy stemming from the virtual destruction of remedies against the predecessor, and the ability of the successor corporation to "spread the risks" through such traditional methods as pricing or the purchase of insurance. There is also the belief that in such business transactions, a corporation could withhold some of the purchase price (escrow) or require an indemnity clause. Of course, a plaintiff could still sue the predecessor if the predecessor were available! This may be difficult if the prior corporation has been liquidated through a Chapter 7 bankruptcy proceeding, or simply has ceased to exist in any practical sense.

- Lessors, bailors, licensors, franchisors: transactions other than sales:

In cases where a sale of a good is not involved, the preferred theory of liability has traditionally been that of negligence rather than strict liability. However, in some leases, where the defect occurs at the beginning of the lease term, courts will impose strict liability, but only if the defendant is in the "business of leasing products of that type." As we have seen in the "7-Up case," in order to hold a franchisor liable in a product defect case, the franchisor must have been intimately involved in the design of the product or must have approved or retained the right to approve any product design. This is often the case in franchising, where 
the franchiser is required to maintain "quality control" over the franchise operation or over any products distributed.

- Employers:

In most cases where an employee has been injured because of the use of a product on the job, and "where the injury arose out of and in the course of employment," states have determined that their workers' compensation programs are the exclusive remedies for any injuries. In workers' compensation cases, damages are scheduled, and they are typically much less than those that are recoverable in products liability cases. In many cases, these damages are compensable through state insurance programs in which employers (and often employees) must participate. A number of states do permit an independent tort action (outside workers compensation) where the employer engages in intentional misconduct, such as the failure to warn of a danger known to the employer that the employee did not know about. (Johns-Manville Products Corp. v. Superior Court of Contra Costa County, 1980) (also known as "The Asbestos Case").

There is also an exception or minority doctrine termed the "dual capacity" doctrine, where the employer is treated the same as a product supplier for the purpose of dangerous machinery or other products furnished by the employer for employee use in the workplace; for example, where the employer furnished the same product for the workplace as it did for the public (a water cooler or coffee pot, for example, manufactured by a defendant, also available to employees on the job). This exception permits an employee to sue an employer in his capacity "other than the employer." The "dual capacity" exception has not gained wide support and is a rather "murky" area of the law.

- Providers of certain services:

Since strict liability will not lie for services generally, negligence actions will predominate. Some interesting sub-topics have arisen in recent years. Product certifiers and testers can be held liable for negligent conduct in the certification or testing process under a theory of "representational conduct." One consideration for not applying a standard of strict liability would be the immense exposure of such parties because of their routine involvement with hundreds and perhaps thousands of different products. Similarly, a Trade Association that establishes "safety guidelines" or safety standards for their members may be held liable for defective products but only under circumstances where they are negligent in creating these industry guidelines or standards.

Professional services most always are decided under a theory of negligence, but under an enhanced view of the reasonable man in the place of the professional. (The Chartered Accountant, 2006).

- Real estate suppliers: 
In a few states (most prominently, New Jersey, California, and Florida), courts have applied a theory of strict liability in the case of mass-produced or manufactured homes. However, in all other cases, the standard of liability would be that of negligence. The standard of strict liability was later extended to business-builder-vendors where multiple properties or where "track houses" were produced. These types of homes are sometimes called "Levitt" homes after the 1950's builder of these large, "cookie cutter" communities.

Lessors may be required to repair conditions in leased premises where courts recognize the implied warranty of habitability or where a state statute requires certain types of repairs.

Occupiers (lessees) may owe an independent duty, judged by a negligence standard, to those parties, termed "business invitees." There are a few cases in which the lessee has been held "strictly liable" to an invitee for such activities termed "abnormally or inherently dangerous activities" like blasting, or where chemicals are stored on the premises, or for other very dangerous activities involving the use of products.

\section{Special Topics and Recent Developments}

Some interesting theories have recently received attention in the area of products liability.

The "enterprise liability" doctrine, found in Burnside v. Abbott Laboratories (1985), is utilized to assess liability against a defendant where no specific evidence exists against that defendant. This doctrine has been most often applied where fungible (interchangeable) goods are involved and where the harm cannot be traced to any specific producer-for example, where a person smokes for over forty years — and over forty different brands!

These are the underlying assumptions inherent in the application of this doctrine:

- The injury-causing product was manufactured by one of a number of manufacturers in an industry who can be identified with reasonable certainty;

- The defendant had joint knowledge of the risks inherent in the product and possessed a joint capacity to reduce those risks;

- Each of the manufacturers failed to take steps to reduce the risk individually, but rather, delegated this responsibility to a trade association or some other third party.

In some states, a defendant can exculpate itself from liability if it can conclusively prove that it did not market the defective product that could have caused plaintiff's injury. So, in this sense, liability is not "strict." 
A second theory is termed "alternative liability." This theory has been applied where the conduct of two or more parties may have been the cause of damage. In such a case, the burden of proof is shifted to each actor to prove that he/she has not caused the harm.

A third theory is called "market share liability." Under the application of this theory, once a party has been included as a defendant under the "enterprise liability" doctrine, the question then becomes how to assess the amount of damages to be awarded against an individual enterprise? Each defendant is presumed to have equal liability unless it can establish actual market share in the relevant geographic area or market.

In Sindell v. Abbott Labs (1980), the court awarded damages against an individual enterprise based upon the respective share of the relevant market.

All of these approaches have been subject to severe criticism as "social engineering, more appropriate for the legislature." Courts have raised several interesting questions in their critiques:

- Should liability be transferred to an entire industry irrespective of an individual manufacturer's connection with a particular injury?

- Once the burden of proof is shifted to an individual defendant, what amount [quantum] of proof is required?

- How do we ascertain the extent of damages that can be apportioned against an individual manufacturer?

No doubt, future cases and future courts (as well as state legislatures or the United States Congress) will attempt to answer these questions as a matter of public policy.

\section{Glossary}

Conspicuous: The UCC defines "conspicuous" as a term "so written, displayed, or presented that a reasonable person against which it is to operate out to have noticed it. Whether a term is 'conspicuous' or not is a decision for the court." [UCC Section 2-201(10)].

Goods: The UCC defines "goods" to include "all things (including specifically manufactured goods) which are movable at the time of identification to the contract of sale." [UCC Section 2-105(1)].

Warranty of Merchantability: "Good to be merchantable must:

(a) pass without objection in trade under the contract description; and

(b) in the case of fungible goods, are of fair average quality within the description' and

(c) are fit for their ordinary purposes for which such goods are used; and 
(d) run, within the variations permitted by the agreement, of even kind, quality and quantity within each unit and among all units involved; and

(e) are adequately contained, packaged and labeled as the agreement may require; and

(f) conform to the promises or affirmations made on the container or label if any."

[UCC Section 2-314(2)].

\section{References}

Becker v. IRM Corp, 698 P.2d 116, Supreme Court of California (1985)

Bell v. Industrial Vangas, Inc., 637 P.2d 266, Supreme Court of California (1981)

Bernard v. Kee Manufacturing Co., Inc., 409 So. 2d 1047, Supreme Court of Florida (1972)

Burnside v. Abbott Laboratories, 505 A.2d 973, Pennsylvania Superior Court (1985)

Cardozo v. True, 342 So. 2d 1053, District Court of Appeals of Florida (1977)

Chartered Accountant. (2006). Negligence: What Does It Mean to Professionals? At icai.org (last visited June 16, 2012)

Dayton v. Peck, Stow, \& Wilcox Co., 739 F.2d 690, $1^{\text {st }}$ Circuit Court of Appeals (1984)

Del Mar Beach Club Owners v. Imperial Contracting, 176 Cal. Rptr. 886, California Court of Appeals (1981)

Elmore v. American Motors Corp., 451 P.2d 84, Supreme Court of California (1969)

Fluor Corp. v. Jeppesen \& Co., 216 Cal. Rptr. 68, California Court of Appeals (1985)

Fuchsgruber v. Custom Accessories, Inc., 628 N.W.2d 833, Supreme Court of Wisconsin (2001)

G-W-L, Inc. v. Robichaux, 643 S.W.2d 392, Supreme Court of Texas (1982)

Gagne v. Bertran, 275 P.2d 15, Supreme Court of California (1954)

Gertz v. Robert Welch, Inc., 418 U.S. 323, United States Supreme Court (1974)

Greenman v. Yuba Power Products, Inc., 377 P.2d 897, Supreme Court of California (1963) 
Harber v. Altec Industries, Inc., 812 F. Supp. 954, District Court, Western District of Missouri (1993)

Hempstead v. General Fire Extinguisher Corp., 269 F. Supp. 109, District Court of Delaware (1967)

Humber v. Morton, 426 S.W.2d 554, Supreme Court of Texas (1968)

Johns-Manville Products Corp. v. Superior Court of Contra Costa County, 27 Cal. 3d 465, California Supreme Court (1980)

Kiely, Terrence F. \& Ottley, Bruce L. (2006). Understanding Products Liability Law. Newark, N.J.: Matthew Bender (a member of the Lexis-Nexis Group)

Klein v. Sears Roebuck and Co., 773 F.2d 21421, $4^{\text {th }}$ Circuit Court of Appeals (1985)

Kosters v. Seven-Up Co., 595 F.2d 347, $7^{\text {th }}$ Cir. Court of Appeals (1979)

Kriegler v. Eichler Homes, Inc., 74 Cal. Rptr. 749, California Court of Appeals, First District (1969)

Lish v. Compton, 547 P.2d 223, Supreme Court of Utah (1976)

Long v. United States Brass Corp., 333 F. Supp. 2d 999, District Court of Colorado (2004)

Mangrum v. Pigue, 2004 Ark. LEXIS 686 at*11, Supreme Court of Arkansas (2004)

Martin v. Ryder Truck Rental, Inc., 353 .2d58, Supreme Court of Delaware (1976)

McNally v. Ward, 14 Cal. Rptr. 260, California Court of Appeals (1961)

Mid Continent Aircraft Corp. v. Curry County Spraying Service, Inc., 572 S.W.2d 308, Supreme Court of Texas (1978)

Mongoven, B. (2007). Food Safety: The Importance of the Retailer and Codex. At www.stratfor.com/food_safety_importance_retailers_and-Codex (last visited June 16, 2012)

Moore v. Mack Trucks, 40 S.W.3d 888, Kentucky Court of Appeals (2001)

Moss v. Polyco, 522 P.2d 622, Supreme Court of Oklahoma (1974)

Newmark v. Gimbel's, Inc., 246 A.2d 11, New Jersey Superior Court, Appellate Division (1968) 
N.J. Stat. Ann. Section 2A:58C-3(a)(2) 2000

Peterson v. Lou Backrodt Chevrolet Co., 329 N.E.2d 785, Supreme Court of Illinois (1975)

Philadelphia Electric Co. v. Hercules, Inc., 762 F.2d 303, $3^{\text {rd }}$ Circuit of Appeals (1985)

Reilly, Marie T. (2003). Making Sense of Successor Liability, 31 Hofstra Law Review 745

Restatement of Torts (1965)

Restatement (Third) of Torts (1998)

Sabloff v. Yamaha Motor Co., Ltd., 273 A.2d 606, New Jersey Appellate Division (1971)

Sindell v. Abbott Laboratories, 607 P.2d 924, Supreme Court of California (1980)

Tennessee Carolina Transportation, Inc. v. Strick Corp., 196 S.E.2d 711, Supreme Court of North Carolina (1973)

Tillman v. Vance Equipment Co., 596 P.2d 1299, Supreme Court of Oregon (1979)

Time Inc. v. Firestone, 424 U.S. 448, United States Supreme Court (1976)

Torres v. Goodyear Tire \& Rubber Co., 786 P.2d 939, Supreme Court of Arizona (1990)

Turner v. Bituminous Casualty Co., 244 N.W. 2d 873, Supreme Court of Michigan (1976)

Uniform Commercial Code, Article 2 and Article 2A (2001)

Vandermark v. Ford Motor Co., 896 P.2d 168, Supreme Court of California (1964)

Weyerhaeuser Co. v. Thermogas Co., 620 N.W.2d 919, Supreme Court of Iowa (2000) 